\title{
The impact of supply effort management, logistics capability, and supply chain management strategies on firm performance
}

\author{
D.M. Sezhiyan* \\ Department of Management Studies, \\ National Institute of Technology, \\ Tiruchirappalli, Tamilnadu State, \\ PIN: 620015, India \\ E-mail: sezhiyan@nitt.edu \\ *Corresponding author

\section{Tom Page} \\ Department of Design and Technology, \\ Loughborough University, \\ Loughborough, Leicestershire, LE11 3TU, UK \\ E-mail: t.page@lboro.ac.uk
}

\section{Paivi Iskanius}

Northern Research and Innovation Platform,

Thule Institute,

University of Oulu, P.O. Box 7300-90014, Finland

E-mail: paivi.iskanius@oulu.fi

\begin{abstract}
The purpose of this research is to examine the relationship among supply effort management, logistics capabilities, and supply chain management strategies on firm performance. A concept model was developed and subsequently five hypotheses were formulated. In order to empirically investigate the concept model, a nationwide survey of supply chain professionals within manufacturing firms was undertaken in India and data were collected. The concept model was tested using structural equation modeling. From the results of SEM analysis, it is found that SCM strategy is positively influenced by supply effort management and logistics capabilities. The overall firm performance is positively impacted by supply effort management, logistics capabilities, and SCM strategy. This study presents valid and reliable metrics that academicians as well as practitioners can use in measuring the supply effort management, logistics capabilities, SCM strategy, and firm performance. The investigated SEM model provides supply chain managers with a useful tool for evaluating and improving efficiency of their current managerial practices.
\end{abstract}

Keywords: firm performance; logistics capabilities; supply chain management strategy; SCMS; supply effort management; structural equation model. 
Reference to this paper should be made as follows: Sezhiyan, D.M., Page, T. and Iskanius, P. (2011) 'The impact of supply effort management, logistics capability, and supply chain management strategies on firm performance', Int. J. Electronic Transport, Vol. 1, No. 1, pp.26-44.

Biographical notes: D.M. Sezhiyan is an Assistant Professor in the Department of Management Studies at National Institute of Technology Tiruchirappalli, India. He is a seasoned sales manager who rendered services in reputed FMCG companies in India and also possesses expert knowledge in cross-functional areas like marketing metrics, brand management, retail, supply chain and media planning.

Tom Page is a Lecturer in Electronic Product Design in the Department of Design and Technology at Loughborough University, UK. He is an External Examiner on Engineering and Manufacturing Programmes at Sheffield Hallam University. His research interests are in the areas of the research and development of computer applications for design and technology education, logistics and supply chain management and electronic design.

Paivi Iskanius is a Project Manager at the University of Oulu, Thule Institute. She coordinates the Northern Research and Innovation Platform project. She has received her MA in Mechanical Engineering in 1988, E-MBA in 2002, Licentiate's degree in Mechanical Engineering in 2004 and $\mathrm{PhD}$ in Industrial Engineering and Management in 2006. All of these degrees are from the University of Oulu. Her research interests are logistics, supply chain management and e-business applications in the business networks, and further, innovation systems and networks and processes. Currently, she has over 90 research publications in these areas.

\section{Introduction}

The firm's strategy depends upon various aspects like the firm's behaviour, performance of the firm against its competitors, scope of business operation and determinants of success factors for the firm (Rumelt et al., 1994). The supply chain management (SCM) strategies have become a contemporary component of a firm's strategy. The success of a firm depends upon its SCM practices and its related strategy (Hartley and Choi, 1996; Degraeve et al., 2000). The globalisation of business has had a tremendous impact on the way companies operate and thus it requires the firms to:

1 integrate its partner within a supply chain context (Cooper et al., 1997)

2 integrate the global manufacturing with logistics capabilities (Bowersox and Closs, 1996)

3 expand its supply chain management strategy (SCMS) and philosophy from its traditional internally focused strategies to modern common goal of efficiency, speed and end customer satisfaction (Harwick, 1997). 
This study pays attention to the basic question of whether the SCM practices and logistics capabilities lead to an improvement in SCM strategies, which, in turn, results in an improvement of the firm's performance. As our objective is to answer this critical question, this research takes cues from the works of Kenneth et al. (2006), Cho et al. (2008), Wisner (2003), and Lu and Yang (2006). This research aims to build a theoretical model for the firm's performance based on context of SCM practices, logistics capabilities, and supply chain strategy. Data collected from a national sample of Indian manufacturers and supply chain professionals are used to assess the model using structural equation methodology. A review of the related literature was undertaken to formulate this research proposition. The methodology employed in this study is then presented. The results of scale assessment and the structural equation modeling were presented. The conclusion, limitation, implications for practicing managers and direction for future research were also discussed in this research paper.

\section{Literature review and research propositions}

\subsection{Supply effort management}

Earlier studies of SCM focused on various dimensions related to several tasks to manage the supply chain. The efforts to manage the supply chain involves various fundamental activities such as managing supplier relationship, supplier involvement in business process, emphasising quality on supplier selection, leaning the levels of supplier base and augmentation of the information. These tasks are efficiently handled by various organisations and further developed to manage the organisation's supply chain in an effective manner. We operationally define these efforts to manage the organisation's supply chain as supply effort management. Managing the supply chain efforts involves a deeper understanding of the boundary spanning roles performed by the business processing and value creation teams in the organisation. The supply effort management involves planning, implementation and regulating the overall functions related to supply chain, which induces the value creation process in the organisation as well. The tasks of supply effort management involves.

\subsubsection{Supplier's long-term and strategic relationship}

The relationship between the business networks has undergone a paradigm shift in today's business scenario. The business networks are based on the long-term relationship, and such relationships are strategically positioned for over time. The long-term perspective between the buyer and supplier increases the intensity of buyer-supplier coordination (Helper, 1991). By developing long-term relationships in the business network, the suppliers will become a part of a well-managed supply chain, which will have an everlasting effect on the competitiveness of the entire supply chain (Choi and Hartley, 1996). Moreover, a high degree of trust will be established through long-term relationships between the buyer and the supplier firms (Bensaou and Venkatraman, 1995). A close relationship among the supply-chain partners leads to sharing of information, risks and rewards as well. Thus, the firms can fully rely on each other and further maintain a mutually beneficial relationship (Guimaraes et al., 2002; Cooper and Ellram, 1993; Landeros and Monczka, 1989). Firms are increasingly relying on their 
suppliers to help them achieve a stronger competitive position, and such a strong position can be achieved only by developing a sustainable competitive advantage created through long-term relationships with their suppliers (Ganesan, 1994). The close long-term working relationships based on trust form the basis of collaborative advantage (Kanter, 1994; Dyer, 2000), which then leads a firm to manage the relationship strategically. Moreover, the firms that foster close, cooperative relationships with their suppliers have reported substantial revenue gains and cost savings (Landeros and Monczka, 1989; Cooper and Ellram, 1993). Zeller and Gillis (1995) demonstrate that businesses can improve their competitiveness and meet their customer's needs by implementing a cooperative, long-term relationship with suppliers. Long-term cooperative relationships have been found to have a positive impact on a firm's competitiveness, especially when the level of uncertainty is relatively high in business situations (Noordewier et al., 1990). The present-day competitiveness has brought a pattern of market-based evolution in SCM. Market orientation of SCM practices has resulted in superior performance in terms of cost, quality, and customer responsiveness (De Toni et al., 1994). Thus, managing for long-term relationship is a major task for supply effort management.

\subsubsection{Supplier involvement}

Supplier involvement is one of the critical aspects of supply effort management. Supplier involvement is important for fundamental design of the product and its development process (Levy, 1997). Tracey (1998) found that the supplier involvement enhances communication and provides avenues for coordinating activities between the suppliers. Effective supplier involvement improves the utility of technology, reduces supply chain costs, and shortens the order cycle (Morgan, 1997). A higher level supplier involvement establishes a pattern of cooperation in continuous improvement efforts (Burt and Soukup, 1985; Cooper and Ellram, 1993; Epatko, 1994; Monczka and Trent, 1991).

\subsubsection{Selection of quality suppliers}

The major focus of the literature on supplier selection is on the different aspects of quality as performance criteria for the selection of a supplier. Dickson (1966) states the important factors to be considered for supplier selection are meeting the requirements of quality standards, delivery time, and performance history. Supplier quality is a critical determinant of the overall product quality and costs, the overall quality performance, which helps supply chain managers to select right sources of supplies with due consideration of time, delivery, and price (Manoochehri, 1984; Treleven, 1987; Baxter et al., 1989).

\subsubsection{Keeping the levels of supplier base lean}

Reduced (lean) supplier base is a unique characteristic of contemporary buyer-supplier relationship (Kekre et al., 1995). With the limited number of suppliers, the firms can forge a close relationship contracting with a smaller number of dedicated suppliers (Kekre et al., 1995; Bozarth et al., 1998; Shin et al., 2000). Supply base reduction policies are positively related to the buyer supplier product design relationship (De Toni et al., 1994). Kale et al. (2000) argued that strategic purchasing contributes to the development of a supply effort management capability in which close working relationships are 
established with a limited number of suppliers. Stanley and Wisner (2001) observed that when limited number of suppliers are properly and selectively used, then the firms achieve better customer responsiveness and Carr and Pearson (1999) found that this practice enhanced the firm's financial performance. The study conducted by Guimaraes et al. (2002) proves that various companies have achieved substantial cost savings by reducing the number of suppliers in their supplier base and deepening the relationships with existing suppliers. Moreover, companies are found to gain significant benefits when they place a larger volume of business with a limited number of suppliers using long-term contracts (Helper and Sako, 1995; Krause and Ellram, 1997; Guimaraes et al., 2002). Companies are streamlining the number of suppliers to obtain competitive advantage (Vijayaraghavan and Raju, 2008). Leaning the supplier base significantly reduces costs and constantly improves quality (Monczka et al., 1993).

\subsubsection{Communication}

A study conducted by Newman and Rhee (1990) found that many problems related to products provided by suppliers were due to poor communication. Another study conducted by Galt and Dale (1991) also states that poor communication is often a fundamental weakness in the interface between a buying firm and its supplier that undermines the buying firm's efforts to achieve higher levels of supplier performance. In managing the supply relationship and its efforts, direct communication with suppliers is inevitable to solve problems (Levy, 1997). Integrated interorganisational communication facilitates a closer relationship among the supply chain members in sharing information, risks and returns; moreover, it indirectly makes an amicable level of compactness among the networks, which promote a comforting level of long-term relationship (Guimaraes et al., 2002; Cooper and Ellram, 1993; Landeros and Monczka, 1989). The different modes of communication platforms such as open source to informal channel pave the way for developing and leveraging the tacit knowledge among the channel partners, which enables the whole network to gain strategic advantage (Nonaka and Takeuchi, 1995). By frequent communication, the firm and its suppliers can enhance their knowledge capabilities and their understating to solve the complex competitive issues by the way of developing innovative solutions. It is evident that the members in the supply chain form strategic alliances for sharing their business time and critical and sensitive information are more successful than others (Mohr and Spekman, 1994). Frequent exchange of information on strategic and operational matters builds greater confidence and reduces dysfunctional conflict between partners (Dwyer et al., 1987; Anderson and Weitz, 1992). If the firm and its suppliers share information and aim to go beyond the business boundaries like design, engineering, quality, materials procurement, and other defined functions between the buyer and the supplier firms, the performance of the supplier becomes superior (Carter and Miller, 1989). Above all, effective communication improves the buying firm's performance (D’Amours et al., 1999; Walton and Marucheck, 1997). Communication is an important factor for the development of supply management capabilities (Zollo et al., 2002), supply chain relationships and strategy (Mohr and Sohi, 1995). It is obvious that effective communication contributes to the development and maintenance of interorganisational routines that enhance a firm's capability for effectively managing strategic alliance (Zollo et al., 2002). 
Thus, all fundamental activities related to managing suppliers' relationship, supplier involvement in business processes, placing emphasis on quality during supplier selection, leaning the levels of supplier base and augmentation of the information are collectively called as supply effort management. Such management leads to the enhancement of SCM strategies and overall performance of the firm as well. Based on the abovementioned relationship, the following hypothesis is derived.

H1 Supply effort management activities are positively associated with SCMS.

H2 Supply effort management activities are positively associated with the firm's performance.

\subsection{Logistics capabilities}

Logistics literature is replete with examples of the effect of logistics capabilities and strategy. It has been found that logistics capability can make major contributions towards the achievement of superior performance and sustained competitive advantage. Olavarrieta and Ellinger (1997) cited that logistics capabilities established by superior firms are difficult to duplicate. Hayes and Pisano (1994) stated that a firm's logistics capability is perceived as one of the important parameters to exceed customer expectations and enhance market and financial performance. Hayes and Pisano (1994) identified five logistics capabilities as drivers to deliver superior value to the customers: cost, quality, flexibility, delivery and innovation. Morash et al. (1996) divided logistics capability into demand-oriented and supply-oriented capabilities. Fawcett and Fawcett (1995) state the following capabilities are essential to achieve optimal operational performance at a global level: delivery speed, quality service, flexibility, cost and innovation. Zhao et al. (2001) examined the effect of logistics capabilities on the firm's performance. They classified logistics capabilities as customer-focused capabilities and information-focused capabilities. The study indicated that customer-focused capabilities and information-focused capabilities respectively affect a firm performance directly and indirectly. The Michigan State University study (GLRT at Michigan State University, 1995) especially revealed how firms used logistics capability to achieve competitive superiority by consistently meeting customer expectations. This body of the research provides the framework for the current study by relating logistics capability to the firm's performance. This gives rise to our next hypothesis.

H3 Logistics capabilities of the firm are positively associated with SCMS.

H4 Logistics capabilities of the firm are positively associated with firm performance.

\subsection{SCM strategies and firm's performance}

Porter (1985) stressed in his early theories by presenting discussion of the value system (more commonly referred to as the supply chain at present) and its impact on competitive advantage. The early literature on supply chain contains studies related to SCM and firm's performance. Armistead and Mapes (1993) found that an increasing level of 
supply chain integration corresponded with increased manufacturing performance. SCM activities were primarily focused on the key process integration throughout the supply chain, which should ultimately lead to a balance between customer requirements and supply chain capabilities (Lummus and Alber, 1997). Tyndall (1988) stated that the focus on opportunities for competitive advantage began shifting from inside the manufacturing plant to relationship with suppliers, and then to closer relationship with customers. Morgan (1997) identified that the firms in mid-1990s had embraced SCM philosophies and practices to achieve cost and time efficiency, taking the purchase and logistics function to a new level. Whereas, firms now use the advanced operational techniques and tools like EOQ, MRP, MRP II, JIT, TQM, and ERP systems as their SCM operational philosophy, which in turn translates into gaining competitive advantage. Bowersox and Closs (1996), and Oliver and Delbridge (2002) have empirically proved the positive impact of SCMS on supply chain performance. A study conducted by Tan (2002) that involved senior supply chain and materials managers concluded that SCM practices positively impact a firm's performance. Wisner (2003) hypothesised SCM strategies as a positive predictor of the firm's performance. Wisner (2003) developed a 12-item scale that measures SCM strategies. The scale was utilised for further scale confirmation of this study. Green et al. (2006) found that there are positive links between SCM strategies and both marketing and financial performance of an organisation. SCM is described as a 'strategic level concept' (Stank et al., 2003). Green et al. (2006) describes SCM is now a strategic tool to improve competitive position and a major concern for top-level management.

The firm's performance has been stated in a variety of ways. Chow et al. (1994) have opined that the definition and measurement of performance is a challenging task for researchers because various organisations have several and frequently conflicting goals. They classified the measurement of firm performance into hard (objective) measures and soft (perceptual) measures. Venkatraman and Ramanujam (1986) have classified performance into financial performance and non-financial performance. Kaplan and Norton (1992) also suggested a 'balance scorecard' framework, which uses both financial and non-financial metrics to measure performance. Many studies have utilised different types of measures for arriving at a firm's performance in the context of SCM. In this study, the firm's performance is represented by five separate measures: financial performance, market performance, perceived product value, customer loyalty and overall competitive capabilities. Based on the theoretical justification and supporting empirical evidences, the next hypothesis is proposed.

H5 SCMS are positively associated with a firm's performance.

\section{The conceptual framework and research process}

\subsection{Research gap and concept formulation}

An integrated and comprehensive approach keeping all factors (supply effort management, logistics capabilities, SCMS and firm performance) as a single combined measure is rarely found in the literature. A logical integration of all such factors leads to formulation of the conceptual model and its hypothesis. Empirically investigating the 
concept model is the main purpose of the research and the formulated concepts model has not been tested previously and it has been found that testing the model is plausible research. The conceptual model is shown in Figure 1. The details of the model are provided in Table 2 . The design of research method is as follows.

Figure 1 Concept model

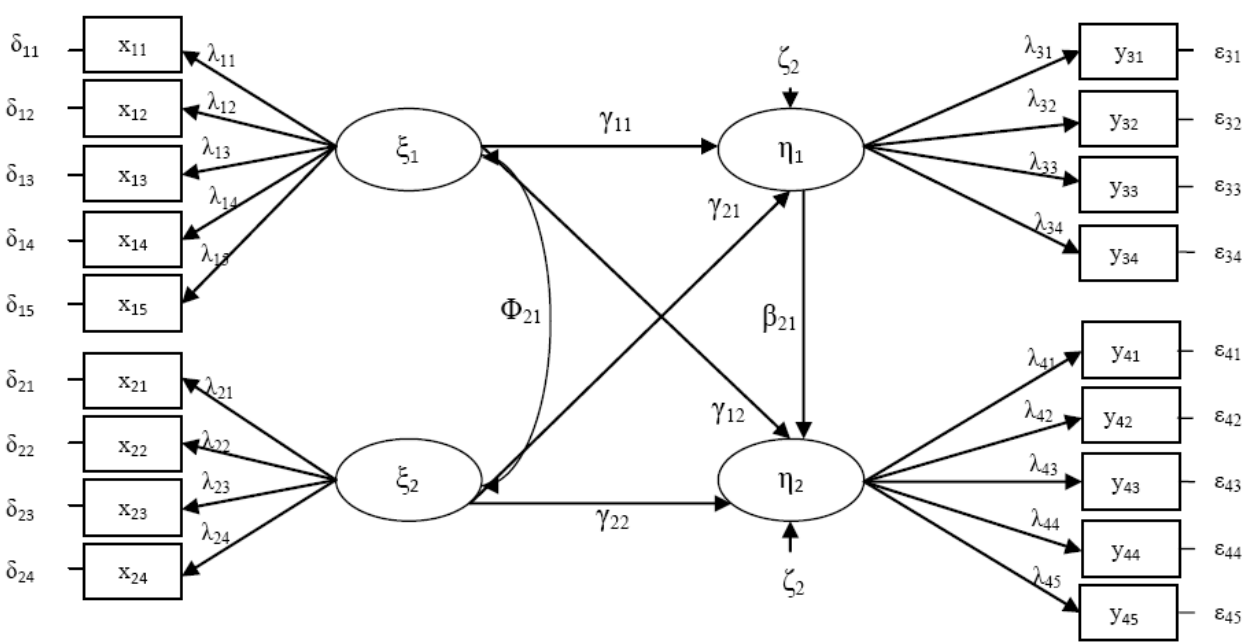

\subsection{Qualitative inquiry and item generation}

A set of measurement items was initially developed based on previous literature in relation to supply chain practices and effort involved in managing the supply chain, logistics capability, supply chain strategies and firm performance. Initially, 12 items for supply effort management constructs were adopted from Choi and Hartley (1996), Burt and Soukup (1985), Cooper and Ellram (1993), and Guimaraes et al. (2002). Eleven items for logistics capability constructs were adopted from Morash et al. (1996) and Cho et al. (2008). Twelve items for supply chain strategy construct were adopted from Wisner (2003) and ten survey items for the firm performance construct were adopted from Fynes and Voss (2002), Zhang et al. (2006), Byrne and Markhan (1991), Heskett et al. (1994), LaLonde et al. (1988), McKee et al. (1989) and Slater and Narver (2000).

An in-depth interview was used to uncover the various aspects involved in supply chain practices and efforts, logistics capability, supply chain strategies and firm performance. The respondents were recruited on a referral basis. Seven SCM faculty members and 22 managers from various cross-functional areas related to supply chain, logistics, procurement, commercial, trade, and quality of various manufacturing organisations participated in the in-depth interview. Interviewers were provided with a brief description of the goal of the in-depth interview and respondents were first asked to think about the effects of supply chain effort, logistics capabilities, supply chain strategy on firm performance based on the developed measurement items. The SCM faculty members and the professional managers were also involved to evaluate the items for content and face validity. The practicing managers and the faculty members were given the conceptual definition of supply effort management, logistics capability, SCMS and firm performance along with illustrative quotes and were instructed to retain items based 
on their representation of SCM domain and clarity of words. The items that were not clear, not representative of domain, or those were possibly open to misrepresentation or convey similar meaning were eliminated from the scale. The authors then reviewed the list of items after elimination and inconsistencies were resolved by discussion among subject matter experts. The resulting items pool contained 33 items, including nine items for supply effort management, eight items for logistics capabilities, ten items for SCM strategies and six items for firm performance. Later, the item pool was submitted to a multisample scale purification and validation process.

\subsection{Scale purification and item analysis}

The breath of theoretical content coverage by an item (subjectivity) and empirical considerations were also employed throughout the scale purification process. Scale purification is concerned with detailed item analysis, confirmatory factor analysis, unidimensionality measure, convergent and discriminant validity. A questionnaire was constructed incorporating the 33 items related to supply effort management (nine items), logistics capability (eight items), SCMS (ten items) and firm performance (six items). The sample frame was constructed mainly to target managers at higher levels in the organisation such as operations managers, supply chain professionals, logistics managers and quality managers from manufacturing companies. Respondents were contacted face-to-face, by telephone and e-mails. A total of 358 questionnaires were returned from all sources. Hair et al. (2006) state that supply effort management models containing five or fewer constructs, each with more than three items (observed variables), and with high item communalities ( 0.6 or higher), can be adequately estimated with a sample as small as 100 to 150 . The measurement model for this research has four constructs, each with three or more observed items. The sample size of 358 is, therefore, considered adequate to support the structural equation analysis necessary to assess this causal model.

First, the corrected item-total subscale correlation was examined for each set of items representing various dimensions (supply effort management, logistics capability, SCMS, firm performance). Items not having a corrected item-total correlation above 0.50 were the candidates for deletion. After careful inspection of item content for domain representation, ten items having corrected item-total correlation of 0.50 and below were subsequently deleted (two items representing supply effort management, three items representing logistics capability, four items representing SCMS and one item representing firm performance). Second, the correlations for items with their hypothesised dimensions were later compared with the remaining dimensions. Items that did not have statistically higher correlation with the dimensions to which they were hypothesised to belong in comparison to other dimensions were subsequently deleted. This procedure resulted in deletion of two items from supply effort management, one item from logistics capabilities and two items from SCMSs, leaving a remaining items pool of 18 items for further analysis. The cronbach coefficient $\alpha$ values greater than or equal to 0.70 indicates sufficient scale or factor reliability (Garver and Mentzer, 1999). The cronbach $\alpha$ values for each of the scales exceeding the recommended values indicate sufficient reliability (Table 1). The variance extracted for three factors are above 0.50 and for one factor is 0.41 . As a whole, the factors are validated in the hypothesised model (Table 2). 
Table 1 Measurement scales

\begin{tabular}{|c|c|c|}
\hline Supply & rt management & (Cronbach alpha 0.924, 5 items) \\
\hline $\begin{array}{l}\text { Please i } \\
\text { supply }\end{array}$ & $\begin{array}{l}\text { cate the importa } \\
\text { in management }\end{array}$ & $\begin{array}{l}\text { oncerns to your organisation's } \\
\text { importance) }\end{array}$ \\
\hline SEM 1 & Establishing su & \\
\hline SEM 2 & Creating avenu & ness process \\
\hline SEM 3 & Selection of $\mathrm{gc}$ & \\
\hline SEM 4 & Leaning the le & \\
\hline SEM 5 & Maintaining fr & rs/customers \\
\hline
\end{tabular}

Please indicate the importance of each of the following issues/concerns to your organisation's logistics capabilities $(1=$ low importance, $7=$ high importance $)$
LC 1 Managing pre and post sales services*
LC 2 Covering the distribution by both widespread and selective way*
LC 3 Ascertain prompt delivery speed and reliability*
LC 4 Efforts to bring low total cost distribution*

\begin{tabular}{ll}
\hline Supply chain management strategies & (Cronbach alpha 0.801, 4 items) \\
\hline Please indicate the importance of each of the following issues/concerns to your organisation's \\
supply chain management strategies ( 1 = low importance, 7 = high importance) \\
SCMS 1 & Searching for new ways to integrate supply chain management activities* \\
SCMS 2 & Establishing communication platform to share customers' future needs* \\
SCMS 3 & Creating a greater level of trust in whole supply chain* \\
SCMS 4 & Extending supply chain beyond the firm's suppliers/customers \\
\hline Firm performance & (Cronbach alpha $0.769,5$ items) \\
\hline Please indicate the importance of each of the following issues/concerns to your firm \\
performance (1 = low importance, 7 = high importance) \\
FP 1 & Performance related to marketing aspects such as market share, sales volume.* \\
FP 2 & Performance related to financial aspects like ROI, ROA, ROS and valuation of the \\
FP 3 & Customer perception on product value* \\
FP 4 & Ability to create customer satisfaction \\
FP 5 & Withstanding in the overall competition position by the firm*
\end{tabular}

Note: *Scale modified based on suggestion by subject matter experts

Table 2 Results of $x$ and $y$ model

\begin{tabular}{llccccc}
\hline Indicator variables and their underlying factor & $\begin{array}{c}\text { Factor } \\
\text { estimate }\end{array}$ & T-value & $\begin{array}{c}\text { Error } \\
\text { term }\end{array}$ & $R^{2}$ & $\begin{array}{c}\text { Variance } \\
\text { extracted }\end{array}$ \\
\hline Supply effort management $\left(\xi_{1}\right)$ & & & & & 0.7167 \\
SEM 1 & Supplier long term relationship $\left(x_{11}\right)$ & 1.30 & 18.56 & 0.84 & 0.67 & \\
SEM 2 & Supplier involvement $\left(x_{12}\right)$ & 1.38 & 21.20 & 0.52 & 0.78 & \\
SEM 3 & Selection of quality suppliers $\left(x_{13}\right)$ & 1.41 & 21.93 & 0.44 & 0.82 & \\
SEM 4 & Leaning supplier base $\left(x_{14}\right)$ & 1.30 & 19.78 & 0.64 & 0.72 & \\
SEM 5 & Communication $\left(x_{15}\right)$ & 1.16 & 16.68 & 0.99 & 0.57 & \\
\hline
\end{tabular}


Table $2 \quad$ Results of $x$ and $y$ model (continued)

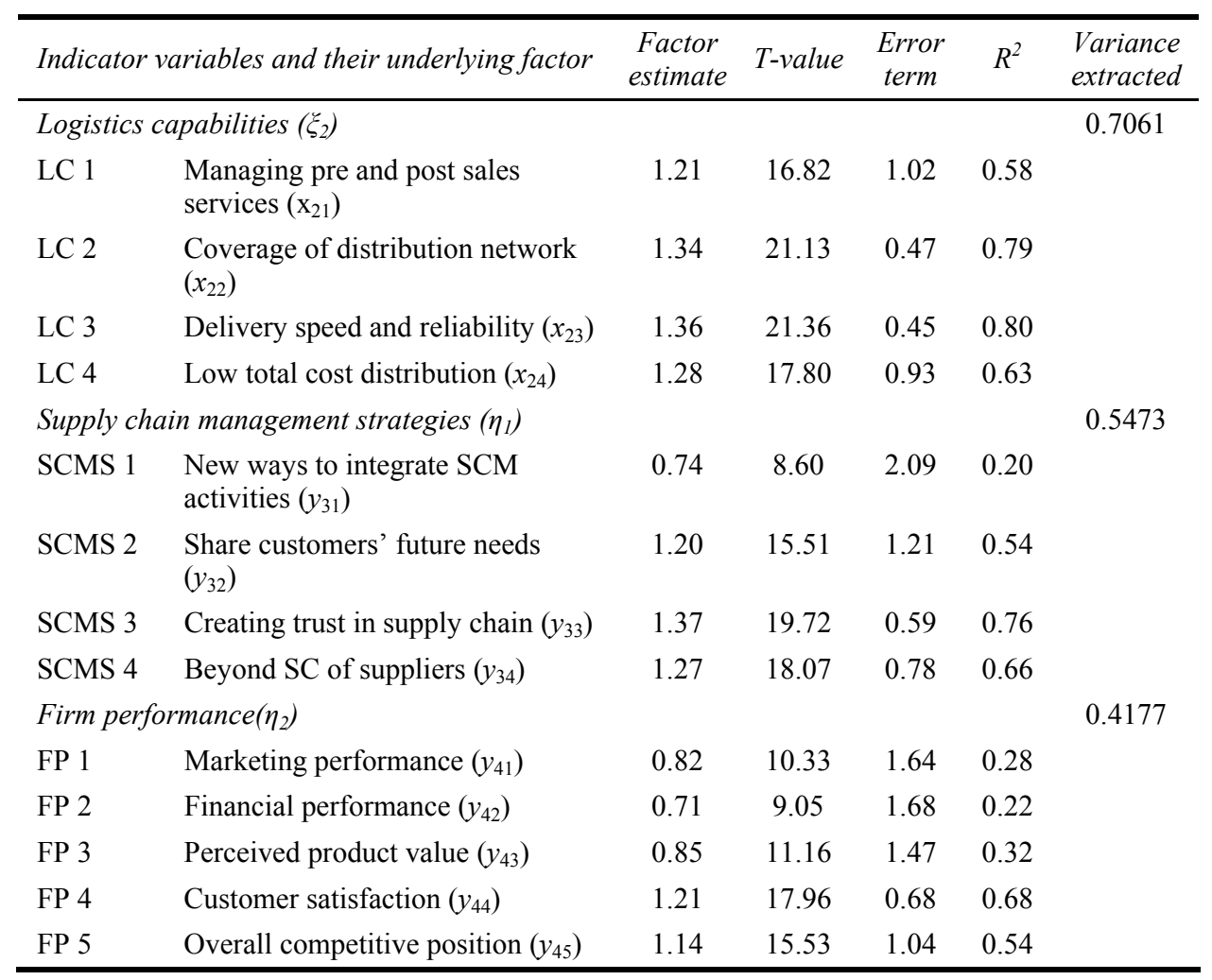

\subsection{Measurement model and validity}

Unidimensionality of the supply effort management, logistics capabilities, SCMS and firm performance scales were assessed by using confirmatory factor analysis as recommended by Gerbing and Anderson (1988). All the four latent construct scales yielded the goodness-of-fit index value is 0.89 , which is close to 0.90 . The value $\geq 0.90$ (GFI) (Ahire et al., 1996) is a reasonably good fit. Non-normed-fit index (NNFI) and comparative-fit-index values $\geq 0.90$ (Garver and Mentzer, 1999), and the root mean square error of approximation (RMSEA) value between 0.05 and 0.08 (Garver and Mentzer, 1999) indicates sufficient unidimensionality. Convergent validity for all the four latent constructs scales was assessed using the normed-fit index coefficient as recommended by Ahire et al. (1996), with values $\geq 0.9$ indicating strong validity (Table 4). Further, evidence for convergent validity is shown by $\mathrm{t}$-values for factor loads in the model, which are greater than 1.96 and are significant at $p \leq 0.05$ (Table 2). Discriminant validity was tested by modifying this model such that the correlations between the factors were set to 1 . Chi-square value for this modified model was $\chi_{[84]}^{2}=369.48$. Chi-square difference test showed the original model in which the correlations between factors were kept independent and which had a significant lower chi-square value $\left(\Delta \chi_{(4)}^{2}=86.52\right)$. This indicates that the scales have discriminant validity (Fornell and Larcker, 1981). 
Table 3 Summary of test results for hypothesised structural model

\begin{tabular}{lcccccc}
\hline Hypothesis & \multicolumn{2}{c}{ Causal path } & Path coefficient & T-value & Hypothesis support & P-value \\
\hline H1 $\left(\gamma_{11}\right)$ & SEM & SCMS & 0.48 & 4.71 & Yes & $p \leq 0.05$ \\
H2 $\left(\gamma_{12}\right)$ & SEM & FP & 0.49 & 4.99 & Yes & $p \leq 0.05$ \\
H3 $\left(\gamma_{21}\right)$ & LC & SCMS & 0.29 & 3.07 & Yes & $p \leq 0.05$ \\
H4 $\left(\gamma_{22}\right)$ & LC & FP & 0.27 & 3.08 & Yes & $p \leq 0.05$ \\
H5 $\left(\beta_{21}\right)$ & SCMS & FP & 0.13 & 1.85 & Yes & $p \leq 0.01$ \\
\hline
\end{tabular}

Note: All of the hypothesis path in the model are positive and significant.

Figure 2 Structural equation model

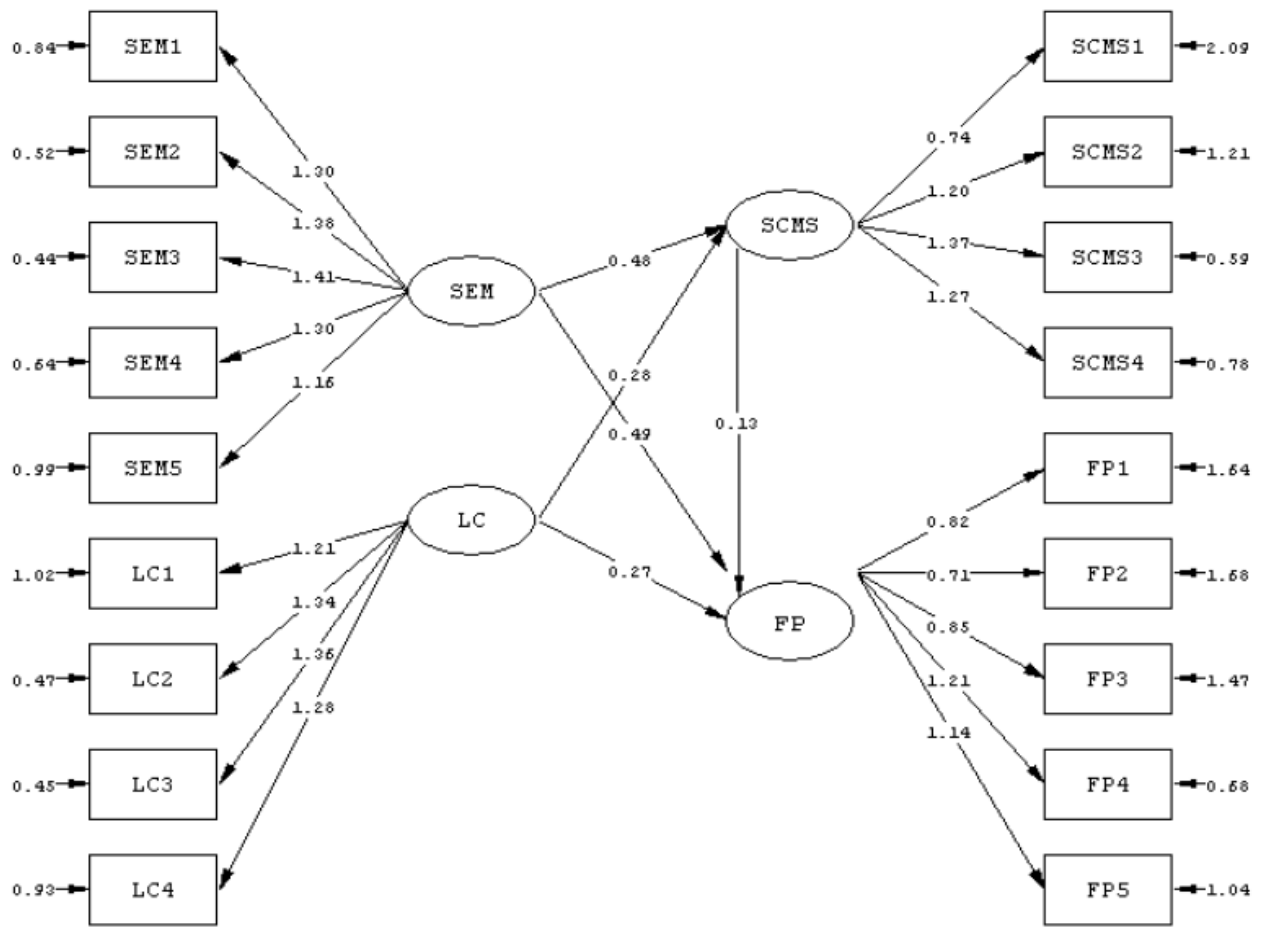

\section{Findings}

The concept model was tested by SEM performed in LISREL $8.80 \mathrm{v}$. The observed variables of endogenous dependent factors and observed variables of exogenous independent factors have shown that both variables of $\mathrm{x}$ and $\mathrm{y}$ model parameter estimates are valid and their t-values are $\geq 1.96$, which have statistical significance at $p$ value $\leq 0.05$ (Table. 2). The outcome of structure model shows that all the path coefficient values are positive; all the t-value of the variables are statistically significant. Thus, the structure model supports all the five hypotheses of the proposed model (Table 3 and Figure 2). For the structural portion of the model, a reasonable fit of the model is 
achieved based on recommended values of fit indices (Table 4). The structural equation of the causal model is

Supply chain management strategy $(\eta 1)=0.48 *$ Supply effort management $\left(\xi_{1}\right)+$ $0.29 *$ Logistics capability $\left(\xi_{2}\right)$, [ Error variance $=0.46, R^{2}=0.54$ ]

Firm Performance $\left(\eta_{2}\right)=0.13 *$ Supply chain management strategy $\left(\eta_{1}\right)+0.49 *$

Supply effort management $\left(\xi_{1}\right)+0.27 *$ Logistics capability $\left(\xi_{2}\right)$,

[ Error variance $=0.31, R^{2}=0.69$ ]

and the reduced form equation for firm performance is

Firm Performance $\left(\eta_{2}\right)=0.56 *$ Supply effort management $\left(\xi_{1}\right)+0.31 *$

Logistics capability $\left(\xi_{2}\right)$, [ Error variance $=0.32, R^{2}=0.68$ ]

Table 4 Fit index of SEM model

\begin{tabular}{|c|c|c|c|}
\hline \multicolumn{2}{|c|}{ Fit index } & $\begin{array}{c}\text { Acceptable threshold levels and } \\
\text { description }\end{array}$ & Fit indices of SEM model \\
\hline \multirow[t]{7}{*}{1} & \multicolumn{3}{|c|}{ Absolute fit indices } \\
\hline & $\chi^{2}$ & $\begin{array}{l}\text { Low } \chi^{2} \text { relative to degree of freedom } \\
\text { with an insignificant } p \text { value. }\end{array}$ & $\begin{array}{l}\chi^{2} \text { for the independent } \\
\text { model with } 153 d f \text { is } \\
13,207.21 . \chi^{2} \text { value is } \\
\text { high due to large sample } \\
\text { size. }\end{array}$ \\
\hline & $\begin{array}{l}\text { Root mean } \\
\text { square error of } \\
\text { approximation } \\
\text { (RMSEA) }\end{array}$ & $\begin{array}{l}\text { Has a known distribution, favours } \\
\text { parsimony. Value } \leq 0.03 \text { represents } \\
\text { excellent fit, value } \leq 0.05 \text { represents } \\
\text { good fit, and value } \leq 0.08 \text { represents } \\
\text { adequate fit. }\end{array}$ & $\begin{array}{l}\text { RMSEA is equal to } 0.077 \\
\text { represents moderate fit. }\end{array}$ \\
\hline & GFI & $\begin{array}{l}\text { Scaled between } 0 \text { and } 1 \text {, with higher } \\
\text { value indicates better model fit. }\end{array}$ & $\begin{array}{l}\text { GFI is equal to } 0.89 \\
\text { represents good fit. }\end{array}$ \\
\hline & AGFI & $\begin{array}{l}\text { Adjusts the GFI based on the number of } \\
\text { parameters in the model. Value } \geq 0.90 \\
\text { represents good fit. }\end{array}$ & $\begin{array}{l}\text { AGFI is equal to } 0.85 \\
\text { represents moderate fit. }\end{array}$ \\
\hline & RMR & Good model have small RMR. & $\begin{array}{l}\text { RMR is equal to } 0.12 \\
\text { represents good fit. }\end{array}$ \\
\hline & SRMR & $\begin{array}{l}\text { Standardised version of RMR. SRMR } \\
\leq 0.08 \text { is good fit }\end{array}$ & SRMS is equal to 0.049 \\
\hline \multirow[t]{4}{*}{2} & \multicolumn{3}{|c|}{ Incremental fit indices } \\
\hline & NFI & $\begin{array}{l}\text { Assessing fit relative to a baseline model } \\
\text { which assumes no covariance between } \\
\text { the observed variable Value } \geq 0.95 \\
\text { indicates strong fit. }\end{array}$ & $\begin{array}{l}\text { NFI is equal to } 0.97 \\
\text { indicates strong fit. }\end{array}$ \\
\hline & NNFI & $\begin{array}{l}\text { Non-normed, values can fall outside the } \\
0-1 \text { range. Favours parsimony. Value } \\
\geq 0.95 \text { indicates strong fit. }\end{array}$ & $\begin{array}{l}\text { NNFI is equal to } 0.97 \\
\text { indicates strong fit. }\end{array}$ \\
\hline & CFI & $\begin{array}{l}\text { Normed, } 0-1 \text { range. Value } \geq 0.95 \\
\text { indicates strong fit. }\end{array}$ & $\begin{array}{l}\text { CFI is equal to } 0.98 \\
\text { indicates strong fit. }\end{array}$ \\
\hline
\end{tabular}


Table 4 Fit index of SEM model (continued)

\begin{tabular}{|c|c|c|c|}
\hline \multicolumn{2}{|c|}{ Fit index } & $\begin{array}{c}\text { Acceptable threshold levels and } \\
\text { description }\end{array}$ & Fit indices of SEM model \\
\hline \multirow[t]{3}{*}{3} & \multicolumn{3}{|c|}{ Fit index combination } \\
\hline & $\begin{array}{l}\text { NNFI and } \\
\text { SRMR }\end{array}$ & $\begin{array}{l}\text { NNFI of } 0.96 \text { or higher and an SRMR OF } \\
0.09 \text { or lower }\end{array}$ & $\begin{array}{l}\text { NNFI is } 0.97 \text { and SRMR } \\
\text { is } 0.049 \text { indicates } \\
\text { excellent combination fit } \\
\text { index }\end{array}$ \\
\hline & CFI and SRMR & $\begin{array}{l}\text { CFI of } 0.96 \text { or higher and a SRMR of } \\
0.09 \text { or lower }\end{array}$ & $\begin{array}{l}\text { CFI is } 0.98 \text { and SRMR is } \\
0.049 \text { indicates excellent } \\
\text { combination fit index. }\end{array}$ \\
\hline
\end{tabular}

\section{Discussion of the result and conclusions}

This research is designed to investigate the association of firm performance with the supply chain and logistics context. The theorised model fits data well and supports all the five hypotheses. The results strongly indicate that the firm performance is influenced by SCM strategies that in turn are influenced by supply chain effort management and logistics capabilities as well. Moreover, this research studies the direct effect and indirect effect of SCMS, supply chain effort management and logistics capabilities on the firm's performance. Thus, the result designates that a SCM strategy mediates the link between supply effort management, logistics capability and firm performance.

Managers of manufacturing sectors need to concentrate and deploy their managerial efforts in SCM activities across the cross-functional areas such as business partnering relationship management, enforcing lean aspect in business model and bringing quality across firm. Successful adaptation of SCM strategies depends on both the tasks related to how managers execute the core activities of supply chain and how companies develop their logistics capabilities. Managers should consider the implications for the overall SCM strategies when making decisions related to two aspects:

1 managing the supply chain (supplier selection, supplier relationship, supplier integration, frequent communication with suppliers)

2 logistics capabilities (pre and post sales services, market coverage, prompt delivery, and low cost distribution).

The theoretical proposition is that success of the SCM strategy depends on the success of efforts made in managing the supply chain efforts and logistics capabilities at the functional level. Moreover, the firm performance depends on how the SCMSs are formulated and executed. This overall result is consistent with previous findings by Carr and Pearson (1999), and Chen et al. (2004) who have confirmed that supplier effort management has a positive effect on business performance. This study has reconfirmed (Carr and Pearson, 1999) argument that if firms make an investment (in-terms of time and effort) in building their relationships with their suppliers, firm's can see an improvement in their own financial performance. This overall result is consistent with previous findings (Baxter et al., 1989; Lin et al., 2005; Monczka et al., 1993). 
To conclude, this paper provides a comprehensive review of the SCM literature, and fills a very crucial gap in the body of SCM literature with respect to the interrelationship between:

a supplier effort management

b logistics capability

c SCMS

d firm performance via the use of conceptual theory building to develop theoretically-based propositions, which are then empirically validated.

Although the purpose of the study was accomplished, several limitations of the study should be noted for further research. First, the study narrowly focused on functional managers working in manufacturing firms in the domains of supply chain, logistics, operations and finance. Corporate level strategic managers can be included in the survey list. Second, the survey is confined to manufacturing firms only and can be extended to service industry also. Third, the supply effort management, logistics capabilities and SCM strategic initiatives will differ from firm to firm in various aspects like a firm's competitive nature, its competitive position, size, structure and content. So, customised research is needed for each industry and the results can be compared between industries.

\section{References}

Ahire, S.L., Golhar, D.Y. and Waller, M.A. (1996) 'Development and validation of TQM implementation constructs', Decision Sciences, Vol. 27, No. 1, pp.23-56.

Anderson, E. and Weitz, B. (1992) 'The use of pledges to build and sustain commitment in distribution channels', Journal of Marketing Research, Vol. 29, No. 1, pp.18-34.

Armistead, C.G. and Mapes, J. (1993) 'The impact of supply chain integration on operating performance', Logistics Information Management, Vol. 6, No. 4, pp.9-14.

Baxter, L.F., Ferguson, N., Macbeth, D.K. and Neil, G.C. (1989) 'Getting the message across? Supplier quality improvement programmes: some issues in practice', International Journal of Operations and Production Management, Vol. 9, No. 5, pp.69-76.

Bensaou, M. and Venkatraman, N. (1995) 'Configurations of interorganizational relationships - a comparison between US and Japanese automakers', Management Science, Vol. 41, No. 9, pp.1471-1492.

Bowersox, D.J. and Closs, D.J. (1996) Logistics Management: The Integrated Supply Chain Process, International ed., McGraw-Hill, Singapore.

Bozarth, C., Handfield, R. and Das, A. (1998) 'Stages of global sourcing strategy evolution: an exploratory study', Journal of Operations Management, Vol. 16, Nos. 2/3, pp.241-255.

Burt, D. and Soukup, W. (1985) 'Purchasing's role in new product development', Harvard Business Review, Vol. 63, No. 5, pp.90-97.

Byrne, P.M. and Markhan, W.J. (1991) Improving Quality and Productivity in Logistics Process, Council of Logistics Management, Oak Brook, IL.

Carr, A.S. and Pearson, J.N. (1999) 'Strategically managed buyer-supplier relationships and performance outcomes', Journal of Operations Management, Vol. 17, No. 5, pp.497-519.

Carter, J.R. and Miller, J.G. (1989) 'The impact of alternative vendor/buyer communication structures on the quality of purchased materials', Decision Sciences, Vol. 20, No. 4, pp.759-776. 
Chen, I.J., Paulraj, A. and Lado, A.A. (2004) 'Strategic purchasing, supply management, and firm performance', Journal of Operations Management, Vol. 22, No. 5, pp.505-523.

Cho, J.J-K., Ozment, J. and Sink, H. (2008) 'Logistics capabilities, logistics outsourcing and firm performance in an e-commerce market', International Journal of Physical Distribution and Logistics Management, Vol. 38, No. 5, pp.336-359.

Choi, T.Y. and Hartley, J.L. (1996) 'An exploration of supplier selection practices across the supply chain', Journal of Operations Management, Vol. 14, No. 4, pp.33-43.

Chow, G., Heaver, T.D. and Henriksson, L.E. (1994) 'Logistics performance: definition and measurement', International Journal of Physical Distribution and Logistics Management, Vol. 24, No. 1, pp.17-28.

Cooper, M.C. and Ellram, L.M. (1993) 'Characteristics of supply chain management and the implications for purchasing and logistics strategy', International Journal of Logistics Management, Vol. 4, No. 20, pp.13-24.

Cooper, M.C., Lambert, D.M. and Pagh, J.D. (1997) 'Supply chain management more than a name for logistics', The International Journal of Logistics Management, Vol. 8, No. 1, pp.1-14.

D’Amours, S., Montreuil, B., Lefrancois, P. and Soumis, F. (1999) 'Networked manufacturing: the impact of information sharing', International Journal of Production Economics, Vol. 58, No. 1, pp.63-79.

De Toni, A., Nassimbeni, G. and Tonchia, S. (1994) 'New trends in the supply environment', Logistics Information Management, Vol. 7, No. 4, pp.41-50.

Degraeve, Z., Labro, E. and Roodhooft, F. (2000) 'An evaluation of vendor selection models from a total cost of ownership perspective', European Journal of Operational Research, Vol. 125, pp.34-58.

Dickson, G.W. (1966) 'An analysis of supplier selection systems and decisions', Journal of Purchasing, Vol. 2, No. 1, pp.5-17.

Dwyer, F.R., Schurr, P.H. and Oh, S. (1987) 'Developing buyer-supplier relationship', Journal of Marketing, Vol. 51, No. 2, pp.11-27.

Dyer, J.H. (2000) Collaborative Advantage: Winning through their Extended Enterprise Supplier Networks, Oxford University Press, New York.

Epatko, E. (1994) 'Suppliers can help meet customer desires', Purchasing, Vol. 117, No. 8, pp.9-11.

Fawcett, S.E. and Fawcett, S.A. (1995) 'The firm as a value-added system: integrating logistics, operations and purchasing', International Journal of Physical Distribution and Logistics Management, Vol. 25, No. 5, pp.24-42.

Fornell, C. and Larcker, D.F. (1981) 'Evaluating structural equation models with unobservable variables and measurement error', Journal of Marketing Research, Vol. 18, No. 1, pp.39-50.

Fynes, B. and Voss, C. (2002) 'The moderating effect of buyer-supplier relationships on quality practices and performance', International Journal of Operations and Production Management, Vol. 22, No. 6, pp.589-613.

Galt, J.D.A. and Dale, B.G. (1991) 'Supplier development: a British case study', International Journal of Purchasing and Material Management, Vol. 27, No. 1, pp.19-24.

Ganesan, S. (1994) 'Determinants of long-term orientation in buyer-seller relationship', Journal of Marketing, Vol. 58, No. 2, pp.1-19.

Garver, M.S. and Mentzer, J.T. (1999) 'Logistics research methods: employing structural equation modeling to test for construct validity', Journal of Business Logistics, Vol. 20, No. 1, pp.33-57.

Gerbing, D.W. and Anderson, J.C. (1988) 'An updated paradigm for scale development incorporating unidimensionality and its assessment', Journal of Marketing Research, Vol. 25, No. 2, pp.186-192.

GLRT at Michigan State University (1995) World Class Logistics: The Challenge of Managing Continuous Change, Council of Logistics Management, Oak Brook, IL. 
Green, K.W., Jr., McGaughey, R. and Casey, K.M. (2006) 'Does supply chain management strategy mediate the association between market orientation and organizational performance?', Supply Chain Management: An International Journal, Vol. 11, No. 5, pp.407-414.

Guimaraes, T., Cook, D. and Natarajan, N. (2002) 'Exploring the importance of business clock speed as a moderator for determinants of supplier network performance', Decision Sciences, Vol. 33, No. 4, pp.629-644.

Hair, J.F., Jr., Black, W.C., Babin, B.J., Anderson, R.E. and Tatham, R.L. (2006) Multivariate Data Analysis, 6th ed., Pearson Prentice-Hall, Upper Saddle River, NJ.

Hartley, J. and Choi, T.Y. (1996) 'Supplier development customers as a catalyst of process change', Business Horizons, Vol. 39, No. 4, pp.37-44.

Harwick, T. (1997) 'Optimal decision making for the supply chain', APICS - The performance Advantage, Vol. 7, No. 1, pp.42-44.

Hayes, R.H. and Pisano, G.P. (1994) 'Beyond world-class: the new manufacturing strategy', Harvard Business Review, Vol. 72, No. 1, pp.77-86.

Helper, S. (1991) 'How much has really changed between US automakers and their suppliers?', Sloan Management Review, Vol. 32, No. 4, pp.15-28.

Helper, S. and Sako, M. (1995) 'Supplier relations in Japan and the United States: are they converging?', Sloan Management Review, Vol. 36, No. 3, pp.77-84.

Heskett, J.L., Jones, T.O., Loveman, G.W., Sasser, W.E. and Schlesinger, L.A. (1994) 'Putting the service-profit chain to work', Harvard Business Review, Vol. 72, No. 2, pp.164-174.

Kale, P., Singh, H. and Perlmutter, H. (2000) 'Learning and protection of proprietary assents in strategic alliances building relational capital', Strategic Management Journal, Vol. 21, No. 3, pp.217-237.

Kanter, R.M. (1994) 'Collaborative advantage - the art of alliances', Harvard Business Review, Vol. 72, No. 4, pp.96-108.

Kaplan, R.S. and Norton, D.P. (1992) 'The balanced scorecard measures that drive performance', Harvard Business Review, Vol. 70, No. 1, pp.71-79.

Kekre, S., Murthi, B.P.S. and Srinivasan, K. (1995) 'Operating decisions, supplier availability and quality: an empirical study', Journal of Operations Management, Vol. 12, Nos. 3/4, pp.387-396.

Kenneth, W.G., McGaughey, R. and Casey, K.M. (2006) 'Does supply chain management strategy mediate the association between market orientation and organization performance?', Supply Chain Management: An International Journal, Vol. 1, No. 5, pp.407-414.

Krause, D.R. and Ellram, L.M. (1997) 'Critical elements of supplier development: the buying-firm perspective', European Journal of Purchasing and Supply Management, Vol. 3, No. 1, pp.21-31.

LaLonde, B.J., Cooper, M.C. and Noordewier, T.G. (1998) Customer Service: A Management Perspective, Council of Logistics Management, Oak Brook, IL.

Landeros, R. and Monczka, R.M. (1989) 'Cooperative buyer/seller relationships and a firm's competitive posture', Journal of Purchasing and Materials Management, Vol. 25, No. 3, pp.9-18.

Levy, D.L. (1997) 'Lean production in an international supply chain', Sloan Management Review, Vol. 38, No. 2, pp.94-102.

Lu, C-S. and Yang, C-C. (2006) 'Evaluating key logistics capabilities for international distribution center operators in Taiwan', Transportation Journal, Vol. 45, No. 4, pp.9-27.

Lummus, R. and Alber, K. (1997) Supply Chain Management: Balancing the Supply Chain with Customer Demand, APICS Educational and Research Foundation Research Paper Series, (707010), January.

Manoochehri, G.H. (1984) 'Suppliers and the just-in-time concept', Journal of Purchasing and Materials Management, Vol. 20, No. 4, pp.16-21. 
McKee, D.O., Varadarajan, P.R. and Pride, W.M. (1989) 'Strategic adaptation and firm performance: a market contingent perspective', Journal of Marketing, Vol. 53, No. 6, pp.21-35.

Mohr, J. and Spekman, R. (1994) 'Characteristics of partnership success - partnership attributes, communication behavior and conflict-resolution techniques', Strategic Management Journal, Vol. 15, No. 2, pp.135-152.

Mohr, J.J. and Sohi, R.S. (1995) 'Communication flows in distribution channels: impact on assessments of communication quality and satisfaction', Journal of Retailing, Vol. 71, No. 4, pp.393-416.

Monczka, R.M. and Trent, R.J. (1991) 'Evolving sourcing strategies for the 1990s', International Journal of Physical Distribution and Logistics Management, Vol. 21, No. 5, pp.4-12.

Monczka, R.M., Trent, R.J. and Callahan, T.J. (1993) 'Supply base strategies to maximize supplier performance', International Journal of Physical Distribution and Logistics Management, Vol. 23, No. 4, pp.42-54.

Morash, E.A., Droge, C.L.M. and Vickery, S.K. (1996) 'Strategic logistics capabilities for competitive advantage and firm success', Journal of Business Logistics, Vol. 17, No. 1, pp.1-22.

Morgan, J.P. (1997) 'Integrated supply chains: how to make them work!', Purchasing, Vol. 122, No. 8, pp.32-37.

Newman, R.G. and Rhee, K.A. (1990) 'A case study of NUMMI and its suppliers', International Journal of Purchasing and Materials Management, Vol. 26, No. 4, pp.15-20.

Nonaka, I.O. and Takeuchi, H. (1995) The Knowledge-Creating Company: How Japanese Companies Create the Dynamics of Innovation, Oxford University Press, New York.

Noordewier, T.G., John, G. and Nevin, J.R. (1990) 'Performance outcomes of purchasing arrangements in industrial buyer-vendor relationships', Journal of Marketing, Vol. 54, No. 4, pp.80-93.

Olavarrieta, S. and Ellinger, A.E. (1997) 'Resources based theory and strategic logistics research', International Journal of Physical Distribution and Logistics, Vol. 27, No. 9, pp.559-587.

Oliver, N. and Delbridge, R. (2002) 'The characteristics of high performing supply chains', International Journal of Technology Management, Vol. 23, Nos. 1-3, pp.60-73.

Porter, M.E. (1985) Competitive Advantage, Free Press, New York.

Rumelt, R.P., Schendel, D.E. and Teece, D.J. (1994) Fundamental Issues in Strategy: A Research Agenda, Harvard Business School Press, Boston, Mass.

Shin, H., Collier, D.A. and Wilson, D.D. (2000) 'Supply management orientation and supplier/buyer performance', Journal of Operations Management, Vol. 18, No. 3, pp.317-333.

Slater, S.F. and Narver, J.C. (2000) 'Intelligence generation and superior customer value', Journal of the Academy of Marketing Science, Vol. 28, No. 1, pp.20-35.

Stank, T.P., Goldsby, T.J., Vickery, S.K. and Savitskie, K. (2003) 'Logistics service performance: estimating its influence on market share', Journal of Business Logistics, Vol. 24, No. 1, pp. $27-55$.

Stanley, L.L. and Wisner, J.D. (2001) 'Service quality along the supply chain: implications for purchasing', Journal of Operations Management, Vol. 19, No. 3, pp.287-306.

Tan, K.C. (2002) 'Supply chain management: practices, concerns, and performance issues', Journal of Supply Chain Management, Vol. 38, No. 1, pp.42-53.

Tracey, M. (1998) 'The importance of logistics efficiency to customer service and firm performance', International Journal of Logistics Management, Vol. 9, No. 2, pp.65-81.

Treleven, M. (1987) 'Single sourcing: a management tool for the quality supplier', Journal of Purchasing and Materials Management, Vol. 23, No. 1, pp.19-24.

Tyndall, G.R. (1988) 'Supply-chain management innovations spur long-term strategic retail alliances', Marketing News, Vol. 22, No. 26, p.10. 
Venkatraman, N. and Ramanujam, V. (1986) 'Measurement of business performance in the absence of objective measures', Strategic Management Review, Vol. 11, No. 4, pp.801-814.

Vijayaraghavan, T.A.S. and Raju, S.B. (2008) 'Supply management orientation and its effect on buyer/supplier performance: some insights from automobile industry in India', Great Lakes Herald, Vol. 2, No. 1, pp.20-35.

Walton, S.V. and Marucheck, A. (1997) 'The relationship between EDI and supplier reliability', International Journal of Purchasing and Materials Management, Vol. 33, No. 3, pp.30-35.

Wisner, J.D. (2003) 'A structural equation model of supply chain management strategies and firm performance', Journal of Business Logistics, Vol. 24, No. 1, pp.1-26.

Zeller, T.L. and Gillis, D.M. (1995) 'Achieving market excellence through quality: the case of Ford Motor Company’, Business Horizons, Vol. 38, No. 3, pp.23-31.

Zhang, F.J., Tian, Y.Z. and Sun, X.L. (2006) 'Empirical analysis of the effects of supplier selection and integration on customer satisfaction and business performance', IEEE Conference Proceedings, pp.931-935, IEEE Singapore.

Zhao, M., Droge, C. and Stank, T.P. (2001) 'The effects of logistics capabilities on firm performance: customer-focused versus information-focused capabilities', Journal of Business Logistics, Vol. 22, No. 2, pp.91-107.

Zollo, M., Reuer, J.J. and Singh, H. (2002) 'Inter-organizational routines and performance in strategic alliances', Organization Science, Vol. 13, No. 6, pp.701-713. 